\title{
Felling Ficus: The Cultural Status of Fig Trees in a Rural Assamese Community, India
}

\author{
H. Eden W. Cottee-Jones ${ }^{1 *}$ and Robert J. Whittaker ${ }^{1,2}$
}

Author Addresses: ${ }^{1}$ Biodiversity Research Group, School of Geography and the Environment, Oxford University Centre for the Environment, University of Oxford, South Parks Road, Oxford, OX1 3QY, United Kingdom. ${ }^{2}$ Centre for Macroecology, Evolution and Climate, Department of Biology, University of Copenhagen, Copenhagen, Denmark.

${ }^{*}$ Corresponding author: henry.cottee-jones@seh.ox.ac.uk

Received: October 17, 2014

Volume: 6(1):89-98

Published: August 19, 2015

(C) 2015 Society of Ethnobiology

\begin{abstract}
Scattered fig (Ficus spp. Moraceae) trees are critically important for biodiversity conservation in tropical rural landscapes. By providing large fruit crops, they help maintain seed dispersal networks and facilitate forest restoration. The conservation of fig trees scattered across rural landscapes is therefore vital for the preservation of ecosystem services and biodiversity beyond the borders of protected areas. Given the threats to scattered fig trees, it is increasingly important to identify potentially effective local conservation strategies that accommodate existing perceptions of their value. We used ethnographic techniques to assess the attitudes of villagers towards fig trees in the village of Komargoan and its surroundings in Assam, India. As reported for other parts of South Asia, we found fig trees have significant sacred status, which included taboos against cutting them down. However, we discovered mixed and sometimes contradictory understandings of the religious attributes of fig trees, which were sometimes believed to be inhabited by gods or ancestral spirits. The benefits most commonly associated with fig trees by interviewees were their aesthetic beauty, large size, and shade during the daytime heat. When the presence of these trees incurred economic costs, their religious, aesthetic, and practical benefits were not sufficient reasons to prevent people from cutting them down, although often saplings would be planted in another place as compensation. Unexpectedly, figs were only planted by respected members of the community, usually older men, who had sufficient social status. Any conservation strategy aiming to sustain the abundance of figs in rural Assam is more likely to be successful if these cultural views are taken into account.
\end{abstract}

Keywords: Assam, Conservation strategies, Cultural values, Ficus spp., Sacred trees, Scattered trees

Supplementary Files available at ojs.ethnobiology.org/index.php/ebl.

\section{Introduction}

Fig (Ficus spp. Moraceae) trees are considered critical components of forest ecosystems across the tropics (Lambert and Marshall 1991; Shanahan et al. 2001; Terborgh 1986). As a result of their mutualistic relationship with pollinator fig wasps (Agaoninae, Chalcidoidea), fig populations produce fruit throughout all seasons of the year (Kinnaird et al. 1996). They also produce very high volumes of fruit, which have unusually high concentrations of rare minerals (O'Brien et al. 1998). These factors make fig trees important food resources for many frugivorous mammals and birds (Shanahan et al. 2001). This interaction with frugivorous species is a major driver of seed dispersal in tropical forests and helps to determine the composition and relative abundances of plant communities (Howe and Miriti 2004). Beyond forests, in human-modified landscapes, a high diversity and abundance of frugivorous birds visit networks of scattered fig trees, suggesting that this relationship remains intact (Barua and Tamuly 2011; Caughlin et al. 2012; Eshiamwata et al. 2006).

The ecological benefits of figs in rural landscapes are dependent on their persistence as networks of scattered trees (Manning et al. 2006). While many scattered tree ecosystems are declining globally (Gibbons et al. 2008; Ismail et al. 2014), scattered fig trees face a peculiar set of challenges due to their close connection to religious and cultural values in some societies (Mawdsley et al. 1998; Sitaramam et al. 2009). For example, in Madagascar, scattered fig trees are not cut because they are associated with the ways of life and activities of ancestors (Martin et al. 2009), while in India several fig species play an important role in Hindu and Buddhist beliefs (Chandrakanth et al. 1990; Dutta 2006; Gadgil and Guha 1993; Kumar 


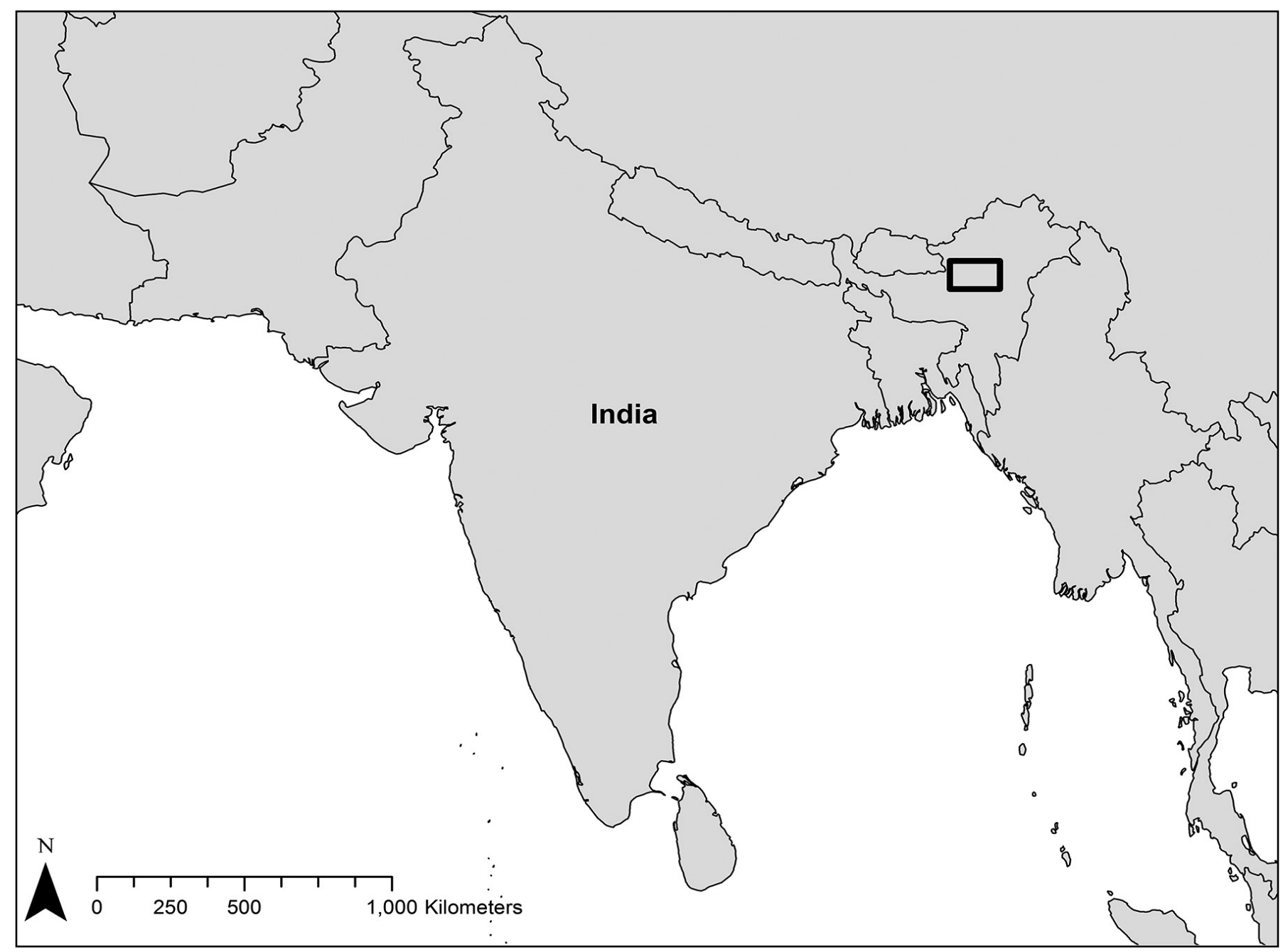

Figure 1. Map of India, with the study location marked by the black box.

et al. 2011). For example, in Hindu tradition, Ficus benghalensis L. Rosales Moraceae features regularly as a holy tree, and it is one of the trees that can be planted to avoid judgment in the afterlife J Jain and Kapoor 2007). For Buddhists, Ficus religiosa L. Rosales Moraceae is the most sacred tree, as it was under this tree that Buddha received enlightenment (Kunwar and Bussmann 2006). While an understanding of cultural values is essential for effective species conservation in human landscapes (Berkes 2004; Chazdon et al. 2009; Harvey et al. 2011), a deeper understanding of the local attitudes towards scattered fig trees in particular may be needed to ensure their conservation.

Fortunately, in some areas, such as northeast India, grassroots conservation movements are increasingly common, where local groups emerge to address issues of concern. Near Kaziranga National
Park in Assam, for example, a group of conservation minded locals launched the successful Naturalist for Rehabilitation of Snakes and Birds initiative in 2008 (NRSB 2014). We sought to support similar locallydefined conservation initiatives by investigating how a culturally and ecologically important tree (figs), could fit with a conservation strategy at a practical level, while also contributing towards academic discourses on aligning local values with conservation priorities.

With these objectives in mind, our research questions were: 1) what religious ideas do people attribute to fig trees?, 2) what are the local attitudes towards fig trees?, 3) what culturally informed strategies may be successful in boosting fig recruitment rates?, and 4) if a conservation body was interested in conserving fig trees in the study area, what local beliefs and norms should be taken into account when developing a strategy? 


\section{Study site and methods}

The study was conducted from October 3 to December 9, 2012 and February 16 to June 22, 2013. The central field site was the village of Komargoan at N26 38.221 E93 45.377 in the Golaghat District of Assam, northeastern India (Figure 1).

The climate is subtropical with a pronounced monsoon season from May to August. Mean annual rainfall is high, with an overall average of $2,900 \mathrm{~mm}$ (GSI 2011). The majority of precipitation (approximately 76\%) falls during the monsoon season. The temperature ranges from 4 to $19^{\circ} \mathrm{C}$ during the winter months (November to February) and 26 to $37^{\circ} \mathrm{C}$ during the summer (May to August), which is also accompanied by very high humidity (with a daily range of 55 to $95 \%$ ).

The original moist subtropical deciduous forest habitat was largely cleared following the local commercialization of tea production in 1840 (Shrivastava and Heinen 2007), resulting in the creation of an agricultural mosaic, with a heterogeneous assortment of smallholder rice cultivation, tea estates, and village home gardens (Jadhav and Barua 2012). Komargoan is located at the junction of two major roads, the AT Road (National Highway 37) and the Dhodar Ali Road. At the time of the study, the population of the village was an estimated 1,462 (GOI 2011) and the primary source of income was rice farming.

Rice paddies were owned by small-holder farmers, who sold the majority of their harvest at local markets. Rice farmers also maintained small gardens (approximately $0.1 \mathrm{ha}$ ) around their homes, where they grew subsistence crops, such as banana (Musa spp. L. Zingiberales: Musaceae), mango (Mangifera indica L. Sapindales: Anacardiaceae), and jack fruit (Artocarpus heterophyllus Lamarck Rosales: Moraceae). Some farmers supplemented their income by selling cash crops (particularly betel nut, Areca catechu L. Arecaceae), cow's milk, or poultry. Most farmers kept small numbers of cows and chickens, while some farmers also kept several ducks, pigs, and goats. Houses in the village were mainly constructed of brick with tin roofing, and had bamboo fences surrounding the home gardens.

To gain a deeper understanding of social relations between local people and scattered fig trees in the study area, detailed observation and open-ended interviews were conducted. Ethnographic observations centered on the experience of daily life within an Ahom community in the village of Komargoan. The
Ahom, the dominant social group in Assam, are Hindu and primarily speak Assamese. In Komargoan, the first author resided with a rice farming family in a recently constructed brick house with a temporary tin roof. Their wealth was typical of the households in the area. They earned money from farming 1.5 ha of rice paddies, and otherwise produced milk, eggs, and fruit in their home garden for subsistence. During this time, the first author helped with the rice harvest, assisted with maintenance of the home garden, cooked, cleaned, and helped with tasks around the house, as well as eating and socializing with the household and neighbors. Such participant observation allowed this researcher to build rapport with the community, and to uncover implicit perspectives towards fig trees that were less apparent in participants' responses to interview questions.

Over the course of the study period, this researcher held discussions with members of the community in Assamese, English, and in Assamese through a translator (who was a native Assamese and fluent English speaker). In cases where a translator was needed, the translator was trained in the importance of providing accurate and detailed accounts of the exchange, with ongoing orientation before and after translated encounters regarding how questions should be framed. Although the use of a translator increased the formality of some discussions, interactions were still conversational, which enabled the first author to ask open ended questions.

To complement the information gathered during participant observation and casual exchanges, we also conducted a series of 12 interviews with key informants who we considered potentially able to offer additional in-depth insights based on their interactions with figs. These informants included women who lived in the proximity of fig trees, village elders, a witch doctor, a priest, and a tea estate manager. We asked each individual a series of 18 standard questions with open-ended responses (see Supplementary Questionnaire 1) and asked follow-up questions that arose during the course of the interview. Interviews were conducted orally and lasted between 40 minutes to one hour. All interviews were transcribed by hand and two were recorded on video. As men are traditionally considered to be heads of the household in Komargoan, it was difficult to recruit female interviewees, and so nine interviewees were male. Interviewees' ages ranged from 29 to 80 years. The topics covered in each interview included: 1) the religious 
Table 1. Scientific, Assamese, Hindi, and English names of the large hemi-epiphytic fig species included in this study. Komargoan village, Assam. All fig species belong to the order Rosales and the family Moraceae.

\begin{tabular}{llll}
\hline Scientific name & Assamese name & Hindi name & English name \\
\hline Ficus altissima Blume & Godha bor & Khunia & Council tree, lofty fig \\
F. benghalensis L. & Borgos & Barh & Indian banyan \\
F. benjamina L. & Juripakri, chilu bor & Pukar & Weeping fig \\
F. curtipes Corner & Kotholua-jori & - & Blunt leaf fig \\
F. elastica Roxb. Ex Hornem. & Rubber gos, atha bor & Bargad & Indian rubber tree \\
F. microcarpa L.f. & Silu bor & Kamarup & Indian laurel, Chinese banyan \\
F. racemosa L. & Dimoru & Gular & Cluster fig \\
F. religiosa L. & Ahot gos & Peepal & Bo tree, peepal tree, sacred fig \\
F. rumphii Blume & Jori gos & Kabaipeepal & Mock peepal tree, Rumpf's fig tree \\
\hline
\end{tabular}

significance of fig trees; 2) the benefits provided by fig trees; 3) the economic and environmental problems associated with fig trees; 4) whether fig trees were cut down in the area; and 5) how people could be encouraged to plant more fig trees. Interviewee names were codified to preserve anonymity and fictional names are used in this paper.

Although there are over 750 species of fig worldwide (Berg and Corner 2005), exhibiting a diverse range of growth strategies, including trees, shrubs, herbs, vines, and creepers (Chaudhary et al. 2012), we confined our study to large, hemi-epiphytic tree species. These species were most readily identifiable as fig species by the local community, and they are also the focus of the Ficus-frugivore conservation literature (Lambert and Marshall 1991; Shanahan et al. 2001). Fig species were identified in a survey of the study area, conducted by a professional botanist from the Assamese non-governmental conservation organization Aaranyak and a botanist from Wild Grass Ecolodge, located near Kaziranga National Park. Photographs of trees which could not be identified with certainty in the field were compared to herbarium specimens at the Assam State Botanical Gardens.

We adopted an inductive thematic approach to data analysis, in which meanings and key issues emerged from the data through the careful analysis of all records. Notes from observations, informal conversations, formal interviews, and videos were used to generate a more comprehensive understanding of the emerging themes.

\section{Religious status of fig in Assam}

There was widespread acknowledgement among the residents of Komargoan that fig trees are sacred. This finding is consistent with previous reports from the Indian Subcontinent (Table 2) (Chandrakanth et al. 1990; Dutta 2006; Gadgil and Guha 1993; Kumar et al. 2011; Sitaramam et al. 2009). We observed temples or shrines were common features at the base of large abot gos (F. religiosa) and bor gos (F. benghalensis) trees (Table 1). These ranged from large modern temples to small shrines, consisting of red banners as gifts to the gods or even posters depicting a god.

Several villagers reported that gods lived in the fig trees (Figure 2). For example, Priest Purshat, who was responsible for a temple at a large bor gos, explained that evidence for gods inhabiting fig trees could be found in the pure white waxy sap they produce when cut, which is the blood of gods. However, there was some variation in reports of which gods in particular inhabited fig trees. Priest Purshat described the God Dangoria as the only god that inhabited the borgos next to his temple. Other villagers identified multiple gods inhabiting fig trees, while Tika Kunwar, a Nepali immigrant, argued that only Durgha, the God of power, inhabited fig trees. There was also some discrepancy over which fig trees held sacred value, with many reporting ahot gos to be the most important 
Table 2. Examples of representations by key informants concerning scattered fig trees in Assam, India. Comments and quotes are organized according to main interview topics.

\begin{tabular}{|c|c|}
\hline Topic & Comments \\
\hline Religious significance of fig trees & $\begin{array}{l}\text { "We attach red cloth to large fig trees as a gift to the gods" (Hondihiram Phukon, el- } \\
\text { der man who planted a F. religiosa tree) } \\
\text { "Even if a tree has no temple, it is still a holy tree, and people will pray } \\
\text { there" (Konkeswar Dhekial, man who lives near a F. benghalensis tree) }\end{array}$ \\
\hline Benefits provided by fig trees & $\begin{array}{l}\text { "Trees don't give us anything useful, except the leaves we use for puja" (Gunin Borah, } \\
\text { elder man who lives near a F. religiosa tree) } \\
\text { "I can't think of illnesses that can be cured using a bor gos. I don't know of anyone } \\
\text { who uses it for sickness" (Suno Gogoi, village witch doctor) }\end{array}$ \\
\hline Problems associated with fig trees & $\begin{array}{l}\text { "Fig trees provide too much shade for tea to grow, and they provide places for insects } \\
\text { to live, which eat the tea plants" (Rajan Surman, tea estate manager) } \\
\text { "The bor gos drinks lots of water, so we cannot build a well near the tree. If the tree } \\
\text { was removed there would be no problem. A well would have to be at least } 9 \text { meters } \\
\text { deep to get water under that tree" (Konkeswar Dhekial, man who lives near a F. ben- } \\
\text { ghalensis tree) }\end{array}$ \\
\hline $\begin{array}{l}\text { Whether fig trees were cut down } \\
\text { in the area }\end{array}$ & $\begin{array}{l}\text { "If someone cuts down a fig they will be punished by the people, and the gods may } \\
\text { kill him in revenge" (Priest Purshat, temple priest) } \\
\text { "We would not cut down this fig, and we would not ask someone to cut it down for } \\
\text { us. Gods live in the tree." (Mimpi Majuli, young mother living near a F. benghalensis } \\
\text { tree) } \\
\text { "If you want to cut a fig, you should first plant another tree nearby, otherwise the } \\
\text { ancestors will be angry" (Gunin Borah, old man who lives near a F. religiosa tree) }\end{array}$ \\
\hline $\begin{array}{l}\text { How people might be encouraged } \\
\text { to plant more fig trees }\end{array}$ & $\begin{array}{l}\text { "Fig trees are planted for your own happiness, but also for the good of the peo- } \\
\text { ple" (Priest Purshat, temple priest) } \\
\text { "Men who can plant fig trees should be about } 60 \text { years old" (Probin Saikia, rice farmer } \\
\text { who planted a F. religiosa tree) }\end{array}$ \\
\hline
\end{tabular}

species, despite Priest Purshat arguing that bor gos is the main god tree. A more widespread view, held by almost every interviewee, was that ancestors inhabited fig trees.

There was some evidence that the sacred value of fig trees was tied to their age and size. For example, Hondihiram Phukon, a man who lived near a small fig tree, commented that ancestors did not live in this particular tree, as it was too young. The link between size and age, and the relationship between large old trees and sacred value may also help explain why slightly smaller species, such as chilu bor (Ficus benjamina Linnaeus Rosales: Moraceae), were not reported to have religious or spiritual significance. Furthermore, temples and shrines were conspicuously absent from young and small trees.

\section{Benefits of figs}

One of the major local uses of fig trees was tied to their sacred value, where the young branches of ahot gos would be harvested on Hindu holy days for use in puja or worship. The branch would be placed in a temple or shrine as an offering to the Hindu deities. We only observed the branches of F. religiosa used for this purpose.

The most commonly cited benefit of scattered fig trees was the shade they provided, with almost all interviewees (10 out of 12 ) reporting that fig trees provided "cool air" (quote from Mimpi Majuli) and "a large shadow" (Dulal Borah) for people and livestock to shelter under during the daytime heat, when the temperature commonly exceed $35^{\circ} \mathrm{C}$. This perception helps explain the occurrence of figs in open agricultural areas, such as paddy fields, and their abundance in public places, such as bus stops and junctions. Many villagers also reported beauty to be a major benefit of fig trees. Participants identified examples of beautiful fig trees, which tended to be old and very large specimens, usually with complex trunk patterns and aerial roots. Indeed, the literal translation of bor gos, the Assamese name for F. benghalensis, is "big tree". In that sense, these beautiful local fig trees exhibited 


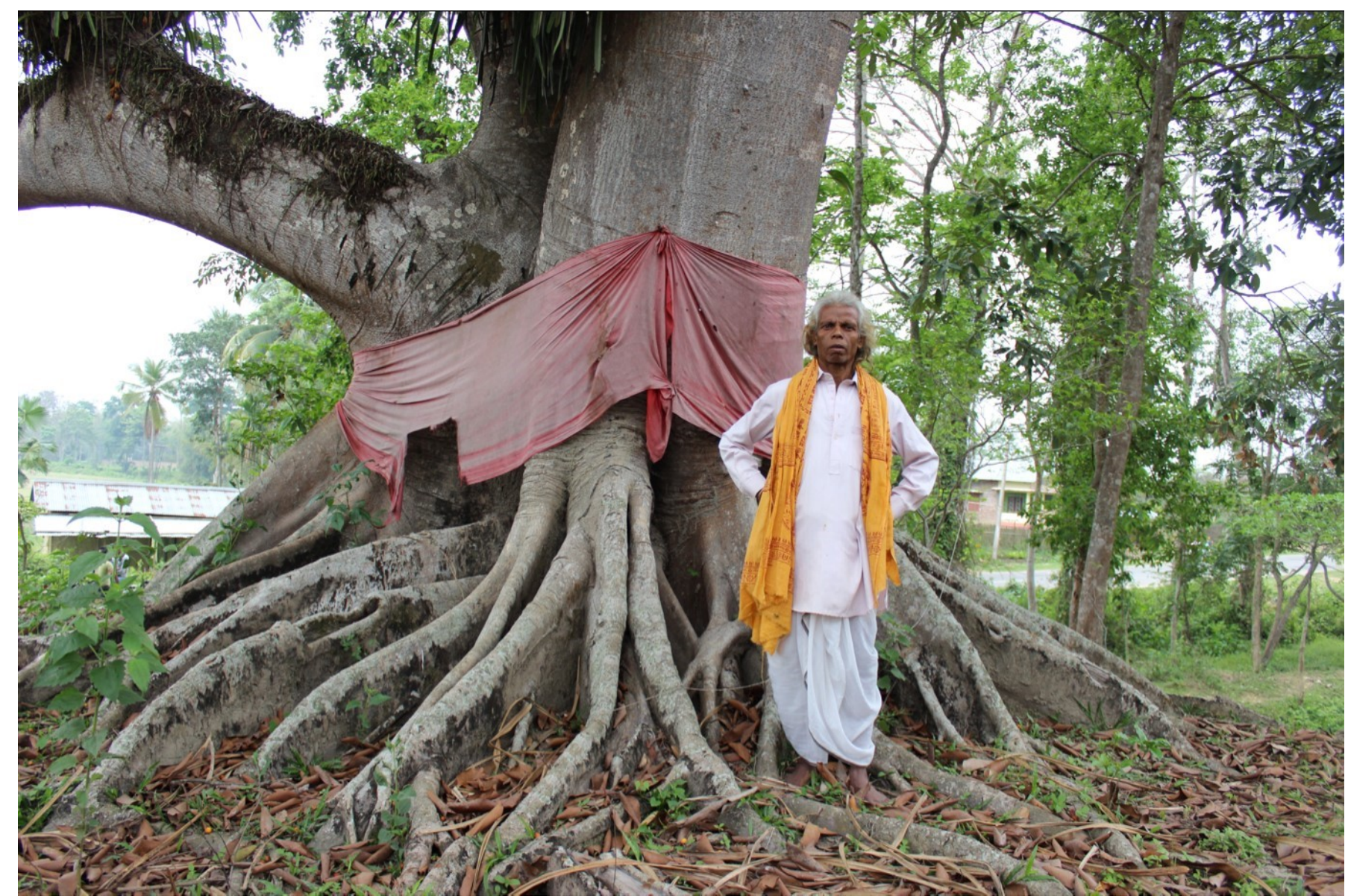

Figure 2. Temple priest in front of a Ficus benghalensis inhabited by gods. South of the village of Komargoan, Assam. Photo: H. Eden W. Cottee-Jones.

similar physical characteristics to heritage fig trees in Southern China, which survive in urban areas as symbols of beauty and nature (Jim 2004).

While many sources identify medicinal properties of fig trees (Dutta 2006; Kumar et al. 2011; Lansky et al. 2008;), the villagers we met did not seem aware of any illnesses that fig products could help prevent or cure. Locals also did not eat fig fruit, although we regularly observed livestock eating fallen fruit. The wood was not used as a building material, for construction, or furniture, as the wood was said to be of very poor quality. Villagers also said it burnt very poorly when used as firewood and was not worth cutting down for that purpose.

\section{Disadvantages of standing fig trees}

Despite their sacred position in Assamese culture, residents' perceptions of the disadvantages and costs of fig trees were apparent. Their large canopies, which were favored in public spaces such as road junctions and markets, were often undesired on private land, where they would very effectively shade out crops and thereby reduce agricultural productivity. Rajan Surman, a manager at a 252 ha tea estate, commented that along with the extensive shade they produce, fig trees are also breeding areas for insect pests that can further reduce productivity. Their extensive but shallow root systems were perceived as a problem for agriculture, creating a barrier to ploughs and competing with crops for moisture and nutrients. The quantity of water fig trees drew from the soil was the focus of a complaint by the 70 year-old Konkeswar Dhekial, who commented that one could not place a pump well under or near a borgos, as it would provide too much competition for water. This is a critical issue, as every house within reach of a groundwater source in Komargoan and neighboring villages received its entire household water supply from a pump well. For these reasons, many villagers described fig trees as problematic species. 


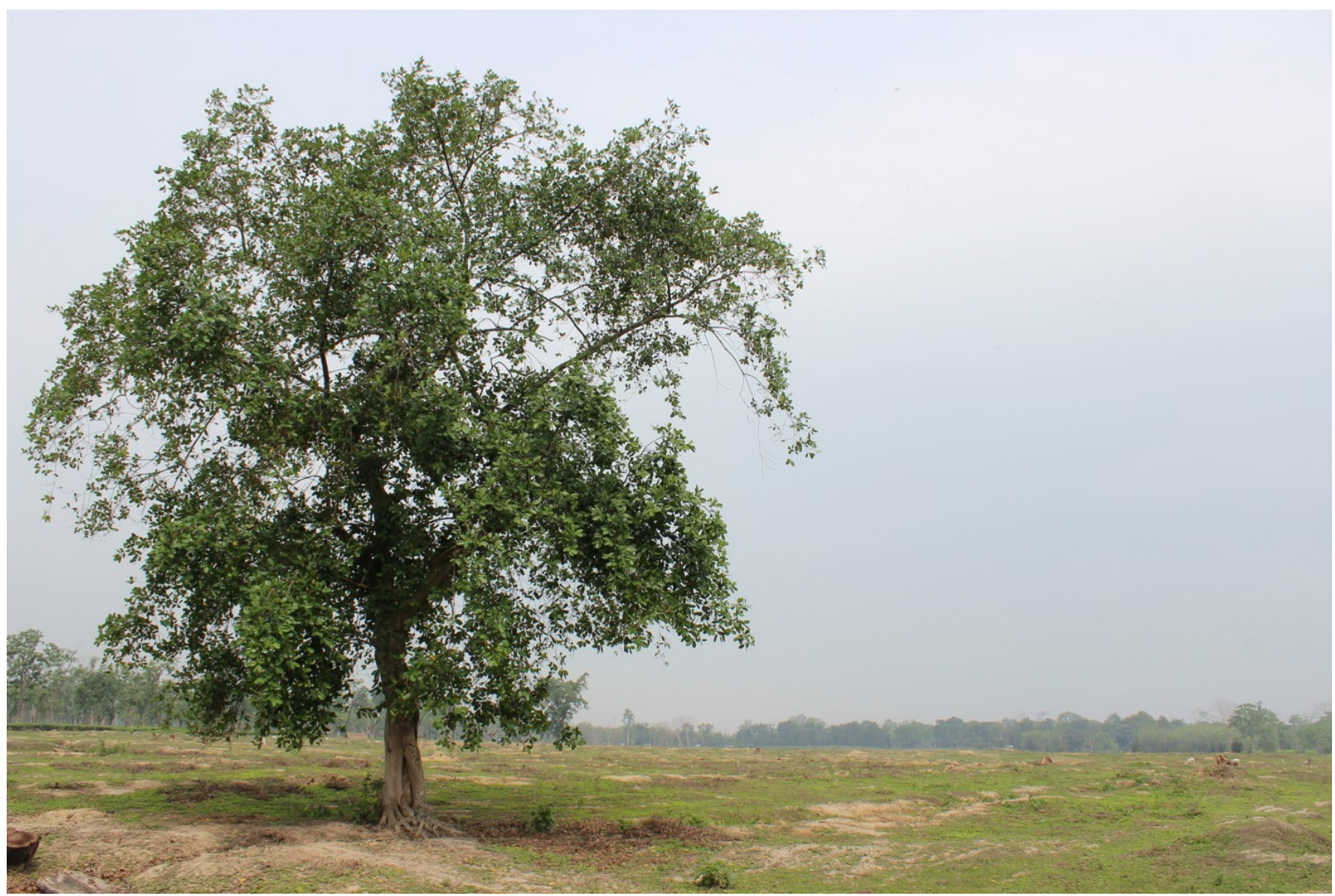

Figure 3. Standing Ficus curtipes (Corner Rosales: Moraceae) surrounded by cleared tea estate, east of the village of Komargoan, Assam. Photo: H. Eden W. Cottee-Jones.

\section{Felling figs}

Given the strong economic complaints made by locals about fig trees, it was interesting to hear their attitudes and stories about cutting fig trees down. During casual conversations, most Komargoan villagers indicated that they did not cut down these trees. For example, while the researcher assisted a local woman with work in her home garden, she emphatically stated that Komargoan villagers would never fell a fig tree. Many other villagers similarly expressed concern about offending ancestors or angering gods by felling these trees. Priest Purshat reported that people who cut fig trees down may be punished or killed by the gods. The perceived power of the gods was also illustrated by the story of Chandrajit Tinta, a mother whose house neighbors a large bor gos. She described a dream where the gods who inhabited the bor gos were angry, as they did not like her boundary fence being so close to their tree, so the next day her husband moved the fence back by six meters.
Similar fears also influenced Shana's decisionmaking. Her family lived under an enormous borgos on a small hill, and she complained that during stormy nights they could not sleep as they were so worried the tree would break and fall on them. However, she said they were too scared to cut the tree down because ancestors live in it.

Some individuals had more pragmatic perspectives. For example, Gunin Borah said that if one needs to cut a fig tree down, another should first be planted for the ancestors. Similarly, Dyoti Soika said before cutting down a tree one should pray at a fig tree and explain to the ancestors why it has to be harvested. Other reasons given for cutting fig trees included preventing trees from encroaching on roads, stopping figs from tangling with power lines, and controlling excessive shading of small village gardens. Even a professional local conservationist, Jintu Tumali, cut a mature fig tree down to improve productivity in his home garden. 
An additional insight into the religious tensions over felling fig was provided by Rajan Surman as he stood in front of a recently cleared tea plantation. According to him, because tea plants become less productive after about 80 years, they are cyclically removed, replaced with nitrogen fixing plants for two years, and then new tea plants and shade trees are planted. Before his plantation was cleared by bulldozer, Rajan had a fairly dense cover of shade trees, including two figs. Afterwards, all the tea plants and shade trees were absent with the exception of the two fig trees, which now stood completely exposed (Figure 3). Rajan reported that the bulldozer driver had refused to remove the fig trees because he considered them sacred. When asked whether he intended to leave them standing, Rajan said that he would employ someone who did not share these beliefs and would be willing to cut the trees down. The wood, he said, would be used to make fence posts. Although it did protect them initially, in this case the sacred status of fig trees was not sufficient to conserve the trees growing in the tea estate. The heterogeneity of local values uncovered here suggests that any conservation organization attempting to conserve scattered fig trees should be cautious of relying too heavily on their sacred status.

\section{Planting figs}

The local reports we received regarding planting fig trees were also fairly complex. There was widespread support among villagers for planting fig trees and many people mentioned having such experience. Figs were planted for a variety of reasons either by seed or cuttings from mature trees. Probin Saikia planted a fig by the road outside his house because he thought it would look beautiful when it was older. Suno Gogoi planted an ahot gos in front of his shop to prevent cars crashing into it, as had happened to a neighboring shop. Hondihiram Phukon planted an abot gos at a road junction near his house to provide shade. Gunin Borah planted a fig tree on the banks of a stream to prevent erosion. Interestingly, all of these people fall into a similar demographic, being fairly elderly men between the ages of 55 and 78. They, along with many others in the community, reported that only senior men (about 55 years or older) had the social status to plant fig trees, an act that is not trivial due to its association with gods and ancestors. In the study area, women and young men are not considered to have sufficient social status to plant figs.
These attitudes may be changing, however. Dulal Borah, who is not religious but whose father planted an ahot gos tree, argued that anyone could plant a fig tree. Bumon Monda, a 32-year-old teacher, said that young people should be encouraged to plant all trees, including figs. When asked about fig planting in the area during an interview, Ripu Khonwar, a 27-year-old rice farmer, suggested that he would plant figs if seedlings were provided. Indeed, if a conservation body did provide fig seedlings, several villagers said they would contribute the materials needed to make a small bamboo fence around saplings in the interest of restoring forests. However, any such intervention should again consider the range of opinions reported here over the significance of planting a sacred tree, to ensure it did not offend the senior men in Komargoan society.

\section{Conclusion}

The residents of the Komargoan village in Assam had a genuine interest in their environment, and sincere concerns about the loss of trees from their agricultural landscape. We gathered ethnographic data on a particular aspect of habitat loss and restoration, namely the conservation of scattered fig trees, in the hope that our research could help guide any locally driven conservation initiatives in the future.

We found that fig trees were widely revered for their sacredness, which had implications for both the felling and planting of figs. While their sacred status should be considered by any local conservation initiative, secular values were also reported to be important for sustaining their presence in the landscape. Values linked to their aesthetic beauty and ability to provide shade may have played a critical role in determining their distribution in Komargoan, as practical considerations also influenced tree cutting and planting: trees that provided too much shade over villagers' home gardens were removed for economic reasons, while trees were planted in hot open areas to lower temperatures for practical reasons. Therefore, at a local level, it may also be worth considering these perspectives in fig conservation.

On a broader scale, the heterogeneity of viewpoints we documented about the sacredness of fig trees, the practical implications of removing them and who should plant them, suggested an important lesson for broader debates about aligning local values, or in this case religious beliefs, to conservation strategies (Bhagwat et al. 2011). Should a conservation initiative 
design a strategy relying on the sacred status of fig trees to preserve them, it might run the risk of alienating some members of the community, and well as suffer vulnerability to practical concerns, such as their beauty and shade, which also drive fig population patterns. We therefore suggest that scholars recommending the alignment of religion with conservation take care to examine the local variations and economic incentives that may also exist, and which could perhaps undermine such an approach.

\section{Acknowledgements}

The authors wish to thank Maan Barua, Manju Barua, Barry and Susan Jones, A.J. Tours and Travel, and Wild Grass Eco Lodge for help facilitating this study. Valuable field assistance was provided by Biju Hazarika, Gokul Munda, Soano Rajbonsi, Nakib Ali, and Somnath Borah. We are grateful to two anonymous reviewers for their helpful comments on earlier versions of this manuscript. Finally, we would like to extend our thanks to all the members of the Komargoan community who helped shape this study.

\section{Declarations}

Permissions: The research was conducted with approval from the Departmental Central University Research Ethics Committee (CUREC) under reference SOGE C1A 14-99. Permission to conduct this field work in India was granted by the High Commission of India, under visa number 4246496. We obtained prior informed consent from all interviewees in the study, along with members of each household and local community who we interacted with on a regular basis. Both interviewees who were filmed gave their prior consent to their responses being recorded in this fashion.

Sources of Funding: Cottee-Jones was supported by a St Edmund Hall Emden-Doctorow Postgraduate Award and Writing-up Grant.

Conflicts of Interest. None declared.

\section{References}

Barua, M. and J. Tamuly. 2011. Conservation of Figs and Frugivores in Assam, India. Final project report. The Rufford Small Grants Foundation, London.

Berg, C. C. and E. J. H. Corner. 2005. Moraceae-Ficus. National Herbarium Nederland, Universiteit Leiden Branch, Leiden, The Netherlands.
Berkes, F. 2004. Rethinking Community-Based Conservation. Conservation Biology 18:621-630.

Bhagwat, S. A., N. Dudley and S. R. Harrop. 2011. Religious Following in Biodiversity Hotspots: Challenges and Opportunities for Conservation and Development. Conservation Letters 4:234-240.

Caughlin, T. T., T. Ganesh and M. D. Lowman. 2012. Sacred Fig Trees Promote Frugivore Visitation and Tree Seedling Abundance in South India. Current Science 102:918-922.

Chandrakanth, M. G., J. K. Gilless, V. Gowramma and M. G. Nagaraja. 1990. Temple Forests in India's Forest Development. Agroforestry Systems 11:199-211.

Chaudhary, L. B., J. V. Sudhakar, A. Kumar, O. Bajpai, R. Tiwari and G. V. S. Murthy. 2012. Synopsis of the Genus Ficus L. (Moraceae) in India. Taiwania 57:193-216.

Chazdon, R. L., C. A. Harvey, O. Komar, D. M. Griffith, B. G. Ferguson, M. Martínez-Ramos, H. Morales, R. Nigh, L. Soto-Pinto, M. van Breugel and S. M. Philpott. 2009. Beyond Reserves: A Research Agenda for Conserving Biodiversity in HumanModified Tropical Landscapes. Biotropica 41:142-153.

Dutta, A. C. 2006. Dictionary of Economic and Medicinal Plants. Doss Publications, Jorhat, India.

Eshiamwata, G. W., D. G. Berens, B. Bleher, W. R. J. Dean and K. Böhning-Gaese. 2006. Bird Assemblages in Isolated Ficus Trees in Kenyan Farmland. Journal of Tropical Ecology 22:723-726.

Gadgil, M. and R. Guha. 1993. This Fissured Land: An Ecological History of India. Oxford University Press, New Delhi.

Gibbons, P., D. B. Lindenmayer, J. Fischer, A. D. Manning, A. Weinberg, J. Seddon, P. Ryan and G. Barrett. 2008. The Future of Scattered Trees in Agricultural Landscapes. Conservation Biology 22:13091319.

GOI (Government of India). 2011. Census of India, 2011. Provisional Population Totals, Assam. Government of India, New Delhi.

GSI, 2011. Geology and Mineral Resources of Assam. Geological Survey of India, No. 30, Part IV, Vol. 2(i): Assam. Government of India. Essar Offset, Guwahati, India. 
Harvey, C. A., C. Villanueva, H. Esquivel, R. Gómez, M. Ibrahim, M. Lopez, J. Martinez, D. Muñoz, C. Restrepo, J. C. Saénz, J. Villacís and F. L. Sinclair. 2011. Conservation Value of Dispersed Tree Cover Threatened by Pasture Management. Forest Ecology and Management 261:1664-1674.

Howe, H. F. and M. N. Miriti. 2004. When Seed Dispersal Matters. BioScience 54:651-660.

Ismail, S. A., J. Ghazoul, G. Ravikanth, C. G. Kushalappa, R. U. Shaanker and C. J. Kettle. 2014. Forest Trees in Human Modified Landscapes: Ecological and Genetic Drivers of Recruitment Failure in Dysoxylum malabaricum (Meliaceae). PLoS ONE 9:e89437.

Jadhav, S. and M. Barua. 2012. The Elephant Vanishes: Impact of Human-Elephant Conflict on People's Wellbeing. Health \& Place 18:1356-1365.

Jain, S. and S. Kapoor. 2007. Divine Botany Universal and Useful but Under Explored Traditions. Indian Journal of Traditional Knowledge 6:534-539.

Kinnaird, M. F., T. G. O'Brien and S. Suryadi. 1996. Population Fluctuation in Sulawesi Red-Knobbed Hornbills: Tracking Figs in Space and Time. The Auk 113:431-440.

Kumar, A., O. Bajpai, A. K. Mishra, N. Sahu, S. K. Behera and L. B. Chaudhary. 2011. Assessment of Diversity in the Genus Ficus L. (Moraceae) of Katerniaghat Wildlife Sanctuary, Uttar Pradesh, India. American Journal of Plant Sciences 2:78-92.

Kunwar, R. M. and R. B. Bussmann. 2006. Ficus (fig) Species in Nepal: A Review of Diversity and Indigenous Uses. Lyonia 11:85-97.

Lambert, F. R. and A. G. Marshall. 1991. Keystone Characteristics of Bird Dispersed Ficus in a Malaysian Lowland Rainforest. Journal of Ecology 79:793-809.

Lansky, E., H. Paavilainen, A. Pawlus and Newman, R. 2008. Ficus spp. (Fig): Ethnobotany and Potential as Anticancer and Anti-Inflammatory Agents. Journal of Ethnopharmacology 119:195-213.

Manning, A. D., J. Fischer and D. B. Lindenmayer. 2006. Scattered Trees are Keystone Structures Implications for Conservation. Biological Conservation 132:311-321.

Martin, E. A., L. Ratsimisetra, F. Laloë and S. M. Carrière. 2009. Conservation Value for Birds of
Traditionally Managed Isolated Trees in an Agricultural Landscape of Madagascar. Biodiversity and Conservation 18:2719-2742.

Mawdsley, N., S. G. Compton and R. J. Whittaker. 1998. Population Persistence, Pollination Mutualisms and Figs in Fragmented Tropical Landscapes. Conservation Biology 12:1416-1420.

NRSB (Naturalist for Rehabilitation of Snakes and Birds). 2014. Naturalist for Rehabilitation of Snakes \& Birds. Available at: http:// www.kaziranganrsb.org/. Accessed on June 21, 2015.

O’Brien, T. G., M. F. Kinnaird, E. S. Dierenfeld, N. L. Conklin-Brittain, R. W. Wrangham and S. C. Silver. 1998. What's so Special about Figs? Nature 392:668.

Shanahan, M., S. So, S. G. Compton and R. Corlett. 2001. Fig-Eating by Vertebrate Frugivores: A Global Review. Biological Reviews of the Cambridge Philosophical Society 76:529-572.

Shrivastava, R. J. and J. Heinen. 2007. A Microsite Analysis of Resource use around Kaziranga National Park, India. Journal of Environment and Development 16:207-226.

Sitaramam, V., S. R. Jog and P. Tetali. 2009. Ecology of Ficus religiosa accounts for its Association with Religion. Current Science 97:637-640.

Terborgh, J. 1986. Keystone Plant Resources in the Tropical Forest. In Conservation Biology, the Science of Scarcity and Diversity, edited by Soulé, M. E., pp. 330344. Sinauer, Sunderland, MA, USA.

Supplementary Files available at ojs.ethnobiology.org/ index.php/ebl.

\section{Biosketches}

Eden Cottee-Jones is a Visiting Research Associate at the University of Oxford, where he recently completed his DPhil in Geography and the Environment. His research interests include conservation beyond protected areas, Ficus-frugivore relationships, and tropical bird conservation.

Robert Whittaker is Professor of Biogeography at the University of Oxford. His current research interests focus on island biogeography and macroecology. In addition, Rob has conducted extensive field research into Ficus in Krakatau, Indonesia, including long distance seed dispersal and plant species assembly. 